\title{
Impact of external and internal factors on management accounting practices: a study of Pakistan
}

\author{
Sidra Shahzadi, Rizwan Khan and Maryam Toor \\ University of Arid Agriculture, Rawalpindi, Pakistan, and \\ Ayaz ul Haq \\ Business Administration Department, Iqra University Islamabad Campus, \\ Islamabad, Pakistan
}

\begin{abstract}
Purpose - The accounting system plays an important role in the company's organizational structure. The purpose of this paper is to demonstrate that the integration of management accounting practices is subject to coordination between external and internal factors and accounting management practices.

Design/methodology/approach - Therefore, the authors move to the contingency model to determine the most significant external "unexpected factors" that explain the introduction of management practices for the management of the various stages of development. The exploratory study examines a sample of Pakistani companies from various sectors.

Findings - This study reveals that the main factors of uncertainty that affect the organizational structure, environmental uncertainty, advanced production technology, just-in-time method strategy, integrated management of quality and structure findings reveal that MAP affected all process and changes all system in simple to complex system in Pakistani's industries.

Practical implications - This study is to acquisition the impact of external factors on management accounting practices, to find the impact of internal factors on management accounting practices, to establish the management accounting practices undertaken by the companies in Pakistan.

Originality/value - The study contributes to the literature by enhancing our understanding for the impact of external and internal factors on management accounting practices in Pakistan.
\end{abstract}

Keywords Environmental uncertainty, Contingency theory, Management accounting practices,

External factors, Internal factors

Paper type Research paper

\section{Background}

Accounting is the process of keeping financial accounts of the organizations. Accounting is an information system for recording economics events. The development of accounting is closely related to writing, money and counting. The money and number may be related to the trading activities of temples.

Management accounting practice is how to use the information given by accounting for decision making. Many writers and researchers write about MAP to avail their own purposes (Shotter, 1999). Management accounting history consist of confirmation that "Lucca Paciolis" introduced double entry book recording system at that time all the people recognize importance for their businesses (Legaspi, 2014).

In previous years a lot of taking have been done to bring changing in MAP. In 1987, a researcher "Johnson" argued that there were not such changes are come in MAP until in

(C) Sidra Shahzadi, Rizwan Khan, Maryam Toor, Ayaz ul Haq. Published in Asian Journal of Accounting Research. Published by Emerald Publishing Limited. This article is published under the Creative Commons Attribution (CC BY 4.0) licence. Anyone may reproduce, distribute, translate and create derivative works of this article (for both commercial and non-commercial purposes), subject to full attribution to the original publication and authors. The full terms of this licence may be seen at http:// creativecommons.org/licences/by/4.0/legalcode

Received 7 August 2018 Accepted 12 October 2018 
AJAR

3,2

212

start of the twentieth century. After these types of criticism there are much management accounting techniques are developed in many organizations which include competitive strategy. Studies reveal that MAP affected all process and changes all system in simple to complex system. Studies also reveal that in which environmental MAP are to be practiced are changed which includes advancement in IT, complex markets, changed organization structure and new practices of management accounting (Kamal, 2015).

Johnson warned the accounting community for the first time that management and other users of information apparently no longer considered management accounting. There were a lot of prescriptive studies about changes in accounting systems, techniques and management practices (Johnson and Kaplan, 1987). More recently, professional accounting offices in the UK and the USA have funded research into changes in management accounting in companies in this country. In the UK, the Chartered Institute of Management Accounting (CIMA) give funds for a long-term study on the development of management accounting in 1995-1998 (Forsaith et al., 2003). Changing in manufacturing system of the organizations and introduced the new technology has increased the competition in the market among organization. It creates stress, risk and uncertainty for organizations. Managers are using MAP for getting the proper information to compete the organizations in the market. Management accounting system provides and monitors all historical information of organization which helps and assists its effort related to competitors.

The contingency theory on management accounting practices and explained that there is no single standard accounting practice that can be applied to all organizations (Otley, 1980). Basically, every organization will have its own accounting management practices. Theory examines a number of factors that support management when deciding on appropriate accounting practices. These factors can be either the technological changes or the infrastructure of an organization. For example, a food production company may want to change the technology used for a more modern, healthy and efficient way of handling, processing and packaging food. Thus, you can consider installing a computer-based system that massively produces its products. However, the type of specialized personnel required to manage such a complex appliance will influence the type of accounting practices selected and the cost of production. Management accounting practice helps to survive an organization in a competitive and ever-changing world because it provides a significant competitive advantage for a management company that supports motivational attitudes and make the necessary cultural values for the achievement of strategic goals. The management accounting mainly deals with the internal needs of the administration. The oriented assessment and development of future valuations in relation to traditional financial accounting, which focuses on historical data on legal economic issues such as ownership, investment, loans, taxation, regulation and the creation of reporting foundations external constant and conservative performance "in compliance with generally accepted accounting principles." Flexibility is an essential feature of management control, because it means that particular attention has been paid to identifying key management needs, many of which may not be accurate (Gichaaga, 2014).

According to the Chandler in the nineteenth century, there were for the first time management accounting system in the USA. This Management Accounting System used simple and complicated accounting methods. To calculate the costs of direct work and the total cost of converting products into assets. Already in the first quarter of the nineteenth century, some companies in the USA, according to Porter (1980) used advanced expenditure accounts. New accounting systems for the monitoring and recording of cash inventories in this period have been developed, as well as for timely administration and a detailed expense declaration (Kamal, 2015). Total quality management assumes that agency employees must 
work together to achieve quality for the needs of their clients. Quality can be achieved by controlling the production/service processes to avoid defects. TQM base on different values and beliefs which company's staff explains with each other. The concept of quality has gone from an unrelated factor, based on imperfect market competition, to considering it as a strategic resource for companies (Gharakhani et al., 2013). Information is more important for decision making in manufacturing company and create awareness among the organizations that giving proper information is more necessary for effective decision (Gichaaga, 2014).

Given the great economic importance of internal and external factors and the economic gap. The purpose of this paper is to get an overview of using MAP in Pakistani companies, their role in the management of different sectors and to examine so many factors that lead to their use and their effect on management accounting practices. Our study has including following research questions:

$R Q 1$. How is the encounter of Environmental uncertainty on MAP?

$R Q 2$. What is the impact of internal factors on MAP?

Our main objectives of this study is to acquisition the impact of external factors on management accounting practices, to find the impact of internal factors on management accounting practices, to establish the management accounting practices undertaken by the companies in Pakistan. This study has useful for practical, theoretical and managerial level. This study will increase the current accounting literature in two important ways. First, this study will provide new experimental evidence using MAP. Second, this study will participate in additional studies in a new context of Pakistan as regard what contingency factor effect the use of MAP (Ahmad, 2012).

\section{Literature review}

Management accounting practices are commonly used in literature review when all of activities done by organization for minimizing their cost, improving efficiency, providing proper information and reducing business resources. Literature shows that most researchers have studied the management accounting practices adoption and implementation on developed and developing countries. The management accounting practices takes an outstanding place in this culture to exchange the modern accounting techniques which are explained briefly by the many contingence factors which include internal and external (Amara and Benelifa, 2017). In organization management accounting plays essential part in the management process. It helps to provide elemental information to the business-like planning, evaluating, controlling and decision making. Manager take information from management accounting and perform activates (Sunarni, 2015).

The effect of immoderate completion in market, economy, less business resources, low business communications among companies, complex business environment and Many technological changes takes companies recognize that the need of management accounting practices to control the cost and decisions which are beneficial for companies (Sleihat $e t$ al., 2012). In 1980, a lot of management accounting techniques established like activity based management, balanced scorecard and strategic management accounting. The purpose of these techniques is to support latest technology and latest management accounting practices for instance cost-volume-profit analysis, total quality management, marginal costing and just- in-time production system (Oyerogba, 2015). Financial and non-financial techniques added in current management accounting. The aim of this process is to give information at operational and organizational level. Management accounting objective is to present non-financial and financial data that are needed for managers, owners, investors and employees (Abdullah et al., 2016). Companies have changed their strategy from traditional accounting practices to the recent use of the advanced management accounting 
AJAR

3,2

214

(AMA) tool. In today's business world, many companies face various challenges to effectively overcome and maintain competitiveness. Many researchers claim that traditional management accounting is no longer adequate for modern production environments, since the production process has changed as the productivity and destructive productivity of the organization have changed. These changes require relevant and timely information relevant to support management for planning and control purposes because the traditional administration did not provide such information. One area in which organizations can adapt effectively is to monitor the movement of competitors (Abdallah, 2017).

Through management accounting practice MNCs reduce their cost and increase the profit and also achieve the global competition, but in KSA smallest companies use in traditional technologies instead of advance technologies (Sulaiman et al., 2004). The management accounting must be used for management accounting practices that the result must be satisfies the management before taking or implementing any decision (Amara and Benelifa, 2017). The internal or external issues affect the MAPs changes in organization (Nishimura, 2005). When the mass increase the firm also increase factors influence on the management accounting practices (Davilla and Foster, 2005, 2007).

\section{Theory of contingency}

There are many techniques are developed to respond the innovations and technology in business environment and all of these changes in management accounting practices have to face the contests of present business needs (Paaso, 2013). Every organization has its own management accounting system which is affected by internal and external factors which can be changed in technology or infrastructure change. Like a food company wants to change its technology for handling, packaging, processing food then they must be installing the computer-based system which is influenced by the management accounting practices (Alleyne and Weekes-Marshall, 2011). Theory shows that there is no single most ideal approach to control organizations which would generally apply to all organizations consistently and in all conditions (Paaso, 2013). Contingency theory claims that there is no universally satisfactory model of organizations that describe the variety of organized design, that's why organization design rest on contingency factors suited to the situation. Contingency variables encompassing business policy, external environment, company mass, and kind affect the sketch of management control system. Contingency approach assumes that the plan and the practices of management control system are impact by the framework in which they are applied (Dropulić, 2013). Micro level hence deals with the practical "doing" of management accounting in the daily life of managerial actors (Šiška, 2016).

The basic resolution of this review of literature on contingency theory is to form an idea of how framework affects operations and results in contingent outcomes in organizational performance. Being familiar with the different types of control challenges organizational framework can impose is also important when considering the responses by management to apply control over various actions. This information will be further polished when designing the study and the measurement instrument.

This study talks the research question on whether contingency variables included strategic business, type of company, size and environment affect the design of management control system.

\section{External factors}

An organization cannot simply evolve to reflect the objectives, motivations or needs of members or its leadership. You must respect the limits imposed by your relationship with the environment. Therefore, the unpredictable state of the environment has an impact on the accounting management system (Amara and Benelifa, 2017). 
Literature shows a contingency relationship between circumstantial variables and Management accounting practices from them many studies explore the effects of circumstantial variables such as environment uncertainty on Management accounting practices. These studies give us an understanding into a "Fit" hypothesis; very rare efforts have been made to connect all variables to performance. In simple words, many literatures claim and showed analytically that if there is high environment uncertainty then it will cause more dependence on Management accounting practices Gul and Chia, 1994. Environmental uncertainty is one of the first conditional factors that examined due to the impact on the development of management accounting practices. When perceived insecurity is low, management can make relatively accurate estimates on the market. Companies with higher environmental safety use more sophisticated methods for management accounting than companies with lower environmental safety. The level of environmental uncertainty affects the level of improvement in management accounting practices (Amara and Benelifa, 2017). The association between the intensity of competition role of benchmarking of the marketing control and management system and a performance from the information provided by the accounting system and the business unit. Being able to compete successfully with market competition in the nature of organizations that use information management system, and improve their result.

\section{Internal factors}

The internal factors of the company are related to its competitive strategy, organizational structure, advance manufacturing technology, total quality management and just in time.

\section{Competitive strategy}

In the management accounting literature, it was considered that there was a general organization strategy and the relationship between strategic decisions and the design of an organization's accounting and control system is analyzed. These studies usually measure strategy as a continuum between companies that follow a "back," "harvest" or "cost leader" strategy and companies that follow a "perspective," "build" or "innovative" strategy although it is a useful indicator of the organization's strategy, this simple continuous process lacks the multidimensional nature of other strategic decisions such as the provision of superior quality compared to the competition, the differentiation of products through the brand image (McLellan and Moustafa, 2011). Findings reveal that every unit in an organization often followed different strategies. The literature of management accounting practices commonly takes organizational strategy as an assumed and then shows the relationship between strategic of business choices and an organization's accounting management control system.

Organizations must change strategies to adapt changes to the environment. However, the institutional approach to organizational change suggests that the organizational structure affects the learning strategy of the organization and the ability to adapt to environmental changes. Using a strategic change in gradual or radical adaptation may lead to a successful change in the structural arrangement of the organization. All elements of the organization, such as structure, strategy, system, people, culture, etc., need to be changed at the same time to achieve greater organizational consistency and efficiency (Ghasemi et al., 2016).

\section{Organization structure}

Literature shows that in the decentralized business system it is the big responsibility of the managers to control the function and get the information that is not available 
AJAR

3,2

216

to top level managers. Decentralized system companies are be successful if their accounting system is strong. A strong management accounting system helps the manager and provides useful information to managers for decision making (Abdel-Kader and Luther, 2008). The structure has been studied by many authors with the intention of a possible factor explaining the integration of accounting management practices. It is presented in two types of opposing structures in relation to participation in the decision. This corresponds to the central structure and the decentralized structure. The result is a positive relationship between decentralization and the state of development of accounting practices. There is no positive relationship between the practice of concentration and the accounting system (Amara and Benelifa, 2017).

\section{Advance manufacturing technology}

To be one of the first conditional variables in connection with management accounting systems, design was a type of production technology. For example, a positive relationship was found between the degree of automation in the production process and how budget systems are used. The traditional performance indicators only have a limited focus, are historical and, in many cases, incomplete. Organizations using AMT need a multidimensional performance measurement (financial and non-financial) system to offer managers with continuous signals, which is more significant in their daily operations and where efforts must be focused (Abdul-Kader and Luther, 2008). As the environment changes and the AMT level increases, managers are expected to use management accounts more often and more frequently than they decide. It is expected that greater acceptance of AMT will be related to the wider use of new accounting systems such as $\mathrm{ABC}$ and non-financial performance indicators.

\section{Total quality management}

Managers and leaders got energy through the fulfilling need of customers which are the main objective of total quality management. Its bring improvement in quality and innovation in an organization. Organizations which are using TQM getting more advantages in term of loyal customers, best quality products, bringing innovations in products (Zehir et al., 2012). However, the effect is significant efforts to investigate the cost of modern management practices the overall management of quality. From the literature, which examines the relationship between the sum quality management and accounting system, increases the auxiliary connecting faith in the non-financial data. Traditional accounting methods that depend on budget discrepancies are inadequate throughout the quality management environment because they do not find the origin of capacity (Gerdin, 2005).

\section{Just in time}

In previous accounting system accountant records thousands of journal entries and ledgers which are most difficult for organizations which are producing many products in a day. Through JIT it is reduce many entries which are very help in accounting system (Dalci, 2006). The literature on the use of JIT in small and medium enterprises, especially in developing countries is limited. The introduction of JIT inventory management system requires well-designed and well-established infrastructure such as efficient transportation system, electronic information network and reliable power source (Mazanai, 2012). As above discussion, the contingency factors (internal and external) as independent variable and MAP as dependent variable can be seen in model as below: The below framework shows the impact of internal and external factors on MAP (Figure 1). 


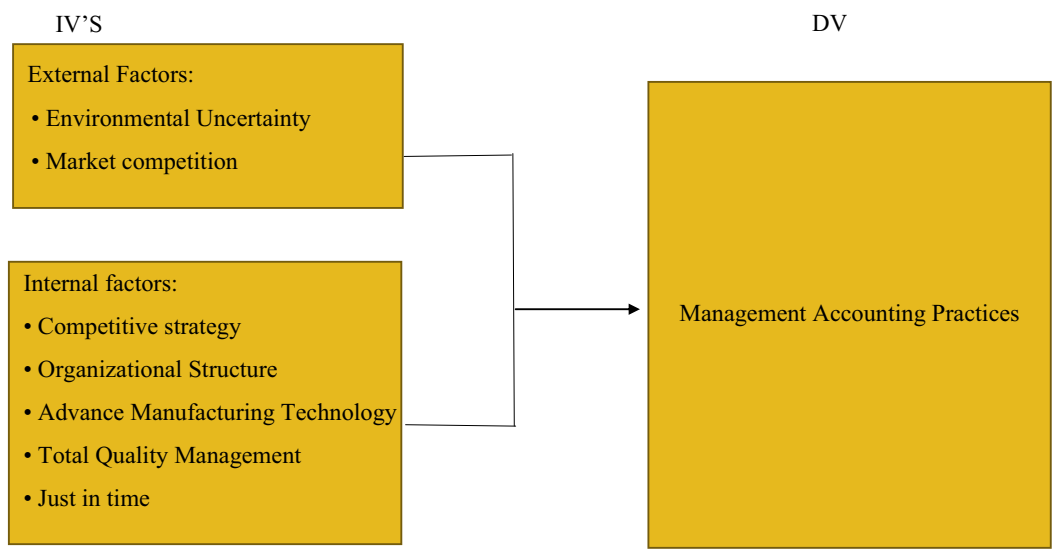

Management accounting practices

\section{Research hypotheses}

H1. "Companies that operate in conditions of high environmental uncertainty integrate management accounting practices."

H2. "Companies with extreme market competition integrate the management accounting practices."

H3. "Companies that adopt the differentiation strategy adopt the most sophisticated management accounting practices."

H4. "Firms with decentralized structures adopt the management accounting practices compared to firms with centralized structure".

H5. "Firms with advanced manufacturing technology (AMT) adopt more sophisticated MAPs."

H6. "Firms with total quality management (TQM) adopt more sophisticated MAPs."

H7. "Firms with a just-in-time (JIT) system adopt more sophisticated MAPs."

\section{Research design and methodology}

A research design provides the basic instructions to execute the project. In particular, a research project must provide the relevant information that is most appropriate respond effectively to research questions or assumptions (Ahmad, 2012). The determination of the sample size is influenced by many factors counts at the same time. The factors include cost and time restrictions, the variability of the data in the target population, the required accuracy of evaluation and if the results should be generalized and, if so, with what degree of confidence (Hair et al., 2008). When deciding on the size of the sample, there is often an exchange between cost and time and the large sample size. A larger sample size obviously requires more data collection and analysis.

An exploratory study was carried out based on a questionnaire on a sample of Pakistani companies from the different fields of activity. The main objective of this research is to examine the impact of business sectors on accounting practices. The research questions in this study refer to the use of MAP by Pakistani different sectors. In demand to collect the required data, we will adopt a questionnaire focusing on a sample of Tunisian companies characterized by a differentiation of internal and external factors. The data which are 
AJAR

3,2

218

collected are "quantitative" in nature which represents the numerical measurement of data in numbers. The purpose of this questionnaire is to find that accounting practices are directly related to these factors. The questionnaire was distributed by direct contact in different sectors. In total, 200 questionnaires were distributed and 183 copies were completed and maintained with 91.5 percent (Table I).

Statistical methods are necessary for conducted analysis so in this study "SPSS 21.0" software was used for processing the questionnaire data. The detail of variables and their references are as follow (Table II):

$$
\mathrm{MAP}=\alpha+\beta_{1} \mathrm{EU}+\beta_{2} \mathrm{MC}+\beta_{3} \mathrm{CS}+\beta_{4} \mathrm{~S}+\beta_{5} \mathrm{AMT}+\beta_{6} \mathrm{TQM}+\beta_{7} \mathrm{JIT}+e .
$$

Above equation shows MAP as a dependent variable and " $\alpha$ " is constant with variables, $\beta_{1}$ shows environmental uncertainty, $\beta_{2}$ shows market competition, $\beta_{3}$ shows competitive strategy, $\beta_{4}$ shows Structure, $\beta_{5}$ shows advance manufacturing Technology, $\beta_{6}$ Total quality management, $\beta_{7}$ shows just in time and e shows error term.

\section{Results}

Table III indicates the correlation between all variables and the level of significance is (0.01). The values which are less than 0.5 are listed in weak correlation. "EU and MC," EU \& CS," "MC and CS," "MC and TQ," "MC and s," CS and S," "CS and TQ, "CS and JIT" and "CS and MAP" having a weak and significant relationship and the direction of relationship is positive among them. The values between 0.5 and 0.6 are listed in medium correlation. "EU and JIT, MC and AMT, MC and JIT, MC and MAP, CS and AMT, S and AMT, S and JIT, S and MAP, AMT and TQ, AMT and MAP, JIT and MAP having a medium and significant relationship and the direction of relationship is positive among them. The values which are more than 0.6 are listed in high correlation. "EU and S, EU and AMT, EU and TQ, EU and MAP, S and TQ, AMT and JIT having a high and significant relationship and the direction of relationship is positive among them.

Table I.

Response rate of the study

\begin{tabular}{lccc}
\hline Elements & Total distributed questionnaires & Collected questionnaires & Rate of participations (\%) \\
\hline Direct contact & 200 & 183 & 91.5
\end{tabular}

\begin{tabular}{|c|c|c|c|c|}
\hline Variables & $\begin{array}{l}\text { Nature of } \\
\text { variable }\end{array}$ & Measurement & $\begin{array}{l}\text { No. of } \\
\text { questions }\end{array}$ & References \\
\hline $\begin{array}{l}\text { Management accounting } \\
\text { practices }\end{array}$ & Dependent & Questionnaire & 26 & $\begin{array}{l}\text { Amara and Benelifa (2017), } \\
\text { Abdel-Kader and Luther (2008) }\end{array}$ \\
\hline $\begin{array}{l}\text { Environmental } \\
\text { uncertainty }\end{array}$ & Independent & Questionnaire & 9 & $\begin{array}{l}\text { Amara and Benelifa (2017), } \\
\text { Abdel-Kader and Luther (2008) }\end{array}$ \\
\hline Market competition & Independent & Questionnaire & 6 & Amara and Benelifa (2017) \\
\hline Competitive strategy & Independent & Questionnaire & 9 & Amara and Benelifa (2017) \\
\hline Organization Structure & Independent & Questionnaire & 5 & Amara and Benelifa (2017) \\
\hline $\begin{array}{l}\text { Advance manufacturing } \\
\text { technology }\end{array}$ & Independent & Questionnaire & 7 & $\begin{array}{l}\text { Egbunike et al. (2015), Abdel-Kader } \\
\text { and Luther (2008) }\end{array}$ \\
\hline Total quality management & Independent & Questionnaire & 5 & Abdul-Kader and Luther (2008) \\
\hline Just in time & Independent & Questionnaire & 8 & Abdul-Kader and Luther (2008) \\
\hline
\end{tabular}

Table II.

Sources of the scale 


\begin{tabular}{|c|c|c|c|c|c|c|c|c|c|}
\hline Correlation & EU & $\mathrm{MC}$ & CS & S & AMT & $\mathrm{TQ}$ & JIT & MAP & lanagement \\
\hline $\begin{array}{l}E U \\
\text { Pearson correlation } \\
\text { Sig. (two tailed) } \\
n\end{array}$ & $\begin{array}{c}1 \\
183\end{array}$ & & & & & & & & practices \\
\hline $\begin{array}{l}M C \\
\text { Pearson correlation } \\
\text { Sig. (two tailed) } \\
n\end{array}$ & $\begin{array}{c}0.492 * * \\
0.000 \\
183\end{array}$ & $\begin{array}{c}1 \\
183\end{array}$ & & & & & & & 219 \\
\hline $\begin{array}{l}C S \\
\text { Pearson correlation } \\
\text { Sig. (two tailed) } \\
n\end{array}$ & $\begin{array}{c}0.411^{* *} \\
0.000 \\
183\end{array}$ & $\begin{array}{c}0.210 * * \\
0.004 \\
183\end{array}$ & $\begin{array}{c}1 \\
183\end{array}$ & & & & & & \\
\hline $\begin{array}{l}S \\
\text { Pearson correlation } \\
\text { Sig. (two tailed) } \\
n\end{array}$ & $\begin{array}{c}0.771 * * \\
0.000 \\
183\end{array}$ & $\begin{array}{c}0.422 * * \\
0.000 \\
183\end{array}$ & $\begin{array}{c}0.360 * * \\
0.000 \\
183\end{array}$ & $\begin{array}{c}1 \\
183\end{array}$ & & & & & \\
\hline $\begin{array}{l}A M T \\
\text { Pearson correlation } \\
\text { Sig. (two tailed) } \\
n\end{array}$ & $\begin{array}{c}0.661^{* *} \\
0.000 \\
183\end{array}$ & $\begin{array}{c}0.558^{* * *} \\
0.000 \\
183\end{array}$ & $\begin{array}{c}0.568^{* *} \\
0.000 \\
183\end{array}$ & $\begin{array}{c}0.559 * * \\
0.000 \\
183\end{array}$ & $\begin{array}{c}1 \\
183\end{array}$ & & & & \\
\hline $\begin{array}{l}T Q \\
\text { Pearson correlation } \\
\text { Sig. (two tailed) } \\
n\end{array}$ & $\begin{array}{c}0.671 * * \\
0.000 \\
183\end{array}$ & $\begin{array}{c}0.422 * * \\
0.000 \\
183\end{array}$ & $\begin{array}{c}0.360 * * \\
0.000 \\
183\end{array}$ & $\begin{array}{c}0.742^{* *} \\
0.000 \\
183\end{array}$ & $\begin{array}{c}0.559 * * \\
0.000 \\
183\end{array}$ & $\begin{array}{c}1 \\
183\end{array}$ & & & \\
\hline $\begin{array}{l}J I T \\
\text { Pearson correlation } \\
\text { Sig. (two tailed) } \\
n\end{array}$ & $\begin{array}{c}0.588^{* *} \\
0.000 \\
183\end{array}$ & $\begin{array}{c}0.575^{* *} \\
0.000 \\
183\end{array}$ & $\begin{array}{c}0.393^{* * *} \\
0.000 \\
183\end{array}$ & $\begin{array}{c}0.575^{* *} \\
0.000 \\
183\end{array}$ & $\begin{array}{c}0.627 * * \\
0.000 \\
183\end{array}$ & $\begin{array}{c}0.775^{* *} \\
0.000 \\
183\end{array}$ & $\begin{array}{c}1 \\
183\end{array}$ & & \\
\hline $\begin{array}{l}\text { MAP } \\
\text { Pearson correlation } \\
\text { Sig. (two tailed) } \\
n\end{array}$ & $\begin{array}{c}0.720 * * \\
0.000 \\
183\end{array}$ & $\begin{array}{c}0.597 * * \\
0.000 \\
183\end{array}$ & $\begin{array}{c}0.260 * * \\
0.000 \\
183\end{array}$ & $\begin{array}{c}0.591 * * \\
0.000 \\
183\end{array}$ & $\begin{array}{c}0.576^{* * *} \\
0.000 \\
183\end{array}$ & $\begin{array}{c}0.591 * * \\
0.000 \\
183\end{array}$ & $\begin{array}{c}0.577 * * \\
0.000 \\
183\end{array}$ & $\begin{array}{c}1 \\
184\end{array}$ & \\
\hline Note: **Correlation & significa & $t$ at the 0. & level (tw & ailed) & & & & & Correlation analysis \\
\hline
\end{tabular}

\section{Regression}

Table IV

\section{Discussion}

The relationship between EU and MAP is highly significant. These findings confirms the empirical results of previous studies such as Kader et al. (2008) and Amara and Benelifa (2017) indicate that companies with a higher level of environmental uncertainty use more complex MAPs than companies with a lower level of environmental uncertainty.

The relationship between MC and MAP is insignificant (0.067) the EU has a significant impact on MAP. These findings confirms the empirical results of previous study of Mia et al. and Amara and Benelifa (2017) explained that the Kruskall-Wallis test shows that there is no significant difference between the three groups of companies in terms of the intensity of competition in the market. This implies that the level of improvement in management accounting practices is not explained by intensity of market competition. 


\begin{tabular}{|c|c|c|c|c|c|c|}
\hline \multirow{3}{*}{$\begin{array}{l}\text { AJAR } \\
3,2\end{array}$} & & \multirow{2}{*}{\multicolumn{2}{|c|}{ Unstandardized coefficients }} & \multirow{3}{*}{$\begin{array}{l}\text { Standardized coefficients } \\
\beta\end{array}$} & & \\
\hline & & & & & \multirow[b]{2}{*}{$T$} & \multirow[b]{2}{*}{ Sig. } \\
\hline & Model 1 & $B$ & SE & & & \\
\hline \multirow{8}{*}{220} & $\begin{array}{l}\text { Coefficient } \\
\text { (Constant) }\end{array}$ & -0.721 & 0.321 & & -2.250 & 0.026 \\
\hline & $\mathrm{EU}$ & 1.094 & 0.123 & 0.880 & 8.859 & 0.000 \\
\hline & $\mathrm{MC}$ & 0.529 & 0.084 & 0.394 & 6.305 & 0.067 \\
\hline & $\mathrm{CS}$ & -0.085 & 0.076 & -0.060 & -1.110 & 0.269 \\
\hline & S & 0.342 & 0.074 & 0.432 & 4.654 & 0.001 \\
\hline & AMT & 0.245 & 0.075 & 0.229 & 3.286 & 0.001 \\
\hline & $\mathrm{TQ}$ & 0.993 & 0.210 & 0.973 & 4.727 & 0.000 \\
\hline & JIT & 1.635 & 0.244 & -1.540 & -6.688 & 0.000 \\
\hline
\end{tabular}

Table IV.

Regression analysis

Notes: $R^{2}=0.673 ; F=60.36$. Dependent Variable: MAP; $R^{2}$ shows the degree of change into DV with respect to IV's In model summary; $\beta$ shows percentage change in DV due to 1 percent change in IV's. $p<0.000$

The relationship between CS and MAP is highly insignificant 0.085 . This results not confirm the previous literature because due to geographically Pakistan is developing country and all previous literature shows results on developed countries but in the future after three to four years results can be significant because Pakistan is moving toward developed economy. The relationship between Structure and MAP is highly significant. These findings confirms the empirical results of previous studies such as Abdul-Kader and Luther (2008) explained that there is a significant relationship between decentralization in organization structure and MAP. Amara and Benelifa (2017) indicate that significant relationship found among structure and MAP and Zainun et al. also show significant relationship between structure and MAP.

The relationship between AMT and MAP is highly significant. These findings confirm the empirical results of previous studies such as Abdul-Kader and Luther (2008), Egbunike et al. (2015) and Ahmad (2012) these all explained that there are positive and significance relationship between advance manufacturing technology and MAP.

The relationship between TQM and MAP is highly significant. These findings confirm the empirical results of previous studies such as Zehie et al. and Abdul-Kader and Luther (2008), which explains that firms are with TQM adopt more MAP and there is significant relationship between TQM and MAP.

The relationship between JIT and MAP is highly significant. These findings confirm the empirical results of previous studies such as Abdul-Kader and Luther (2008), and Dalci (2006) indicates that just in time has significant impact on MAP.

\section{Conclusion}

In this paper, we examine the impact of internal and external characteristics of companies on the management accounting practices. In particular, we investigate to what extent the characteristics associated with the internal and external environment of a company. The literature conducted is more limited and inside the Pakistan, with our preliminary work, it let us to think that the diversification of the complexity of management accounting is partly explained by contingent variables.

Results investigate that management accounting differences significantly affected by environmental uncertainty, these variables the direction of the significant relationships confirms a prior expectations. On the other hand, our expectations about the significant relationships between the market competition (H2) and competitive strategy $(H 3)$ are not supported by the data and these are shown as an insignificant.

This study suggests that there is need of awareness and understanding the use of MAP in small firms in Pakistan so that the small firms can enhance their productivity at low cost and increased their performance. 
This study will provide benefit to the managers whom are working in different sectors for maximization of profit. This study represents significant results and the concepts of MAP become popular in Pakistan. Organizations can use the knowledge to implement MAP policies to protect them from losses. The data collected from 200 different companies are too small compared to previous researches. Finally, research in this field can be developed by comparing the situation in Pakistan with the introduction of a MAP to other developing countries, studying differences in cultural factors and other conditional factors.

\section{References}

Abdallah, W. (2017), "Management accounting practices in the global business environment: the case of the middle east”, التجارة كلية مؤتمرات.

Abdel-Kader, M. and Luther, R. (2008), "The impact of firm characteristics on management accounting practices: a UK-based empirical analysis", The British Accounting Review, Vol. 40 No. 1, pp. 2-27.

Abdullah, N., Wahab, R.A., Din, N.M. and Azam, F.A.A. (2016), "Self-monitoring action skill acquisition system: an integrated approach to teaching and learning", Regional Conference on Science, Technology and Social Sciences (RCSTSS 2014), Springer, Singapore, pp. 483-493.

Ahmad, K. (2012), "The use of management accounting practices in Malaysian SMEs", available at: https://ore.exeter.ac.uk/repository/handle/10036/3758 (accessed July 15, 2017).

Alleyne, P. and Weekes-Marshall, D. (2011), "An exploratory study of management accounting practices in manufacturing companies in Barbados", International Journal of Business and Social Science, Vol. 2 No. 10.

Amara, T. and Benelifa, S. (2017), "The impact of external and internal factors on the management accounting practices", International Journal of Finance and Accounting, Vol. 6 No. 2, pp. 46-58.

Dalci, İ. (2006), "The effect and implementation of just in time system from a cost and management accounting perspective", Çukurova Üniversitesi Sosyal Bilimler Enstitüsü Dergisi, Vol. 15 No. 1.

Davilla, A. and Foster, G. (2005), "Management accounting systems adoption decisions: Evidence and performance implications from early-stage/startup companies", The Accounting Review, Vol. 80 No. 4.

Davilla, A. and Foster, G. (2007), "Management control systems in early startup companies", The Accounting Review, Vol. 82 No. 4.

Dropulić, I. (2013), "The effect of contingency factors on management control systems: a study of manufacturing companies in Croatia”, Economic Research-Ekonomska Istraživanja, Vol. 26 No. S1, pp. 369-382.

Egbunike, A.P., Egolum, P.U. and Agwaramgbo, J.C. (2015), "Management accounting practices in a changing advanced manufacturing technology environment".

Forsaith, D., Tilt, C.A. and Xydias-Lobo, M. (2003), "The future of management accounting: a South Australian perspective", School of Commerce, Flinders University.

Gerdin, J. (2005), "Management accounting system design in manufacturing departments: an empirical investigation using a multiple contingencies approach", Accounting, Organizations and Society, Vol. 30 No. 2, pp. 99-126.

Gharakhani, D., Rahmati, H., Farrokhi, M.R. and Farahmandian, A. (2013), "Total quality management and organizational performance", American Journal of Industrial Engineering, Vol. 1 No. 3, pp. 46-50.

Ghasemi, R., Azmi Mohamad, N., Karami, M., Hafiz Bajuri, N. and Asgharizade, E. (2016), "The mediating effect of management accounting system on the relationship between competition and managerial performance", International Journal of Accounting and Information Management, Vol. 24 No. 3, pp. 272-295.

Gichaaga, P.M. (2014), "Effects of management accounting practices on financial performance of manufacturing companies in Kenya", Research project for the master of science in finance degree.

Gul, F.A. and Chia, Y.M. (1994), "The effects of management accounting systems, perceived environmental uncertainty and decentralization on managerial performance: a test of three-way interaction”, Accounting, Organizations and Society, Vol. 19 Nos 4-5, pp. 413-426.
Management accounting practices 
AJAR

3,2
Hair, J.F., Celsi, M.W., Ortinau, D.J. and Bush, R.P. (2008), "Essentials of marketing research”, McGraw-Hill/ Higher Education, International Journal of Business and Social Science, Vol. 2 No. 9, pp. 49-58.

Johnson, T.H. and Kaplan, R.S. (1987), Relevance Lost: The Rise and Fall of Management Accounting, Harvard Business School Press, Boston, MA, 269pp.

Kamal, S. (2015), "Historical evolution of management accounting", The Cost and Management, Vol. 43 No. 4, pp. $12-19$.

Legaspi, J.L. (2014), The Impact of Management Accounting Literature To Practice: A Study of Management Accounting Concepts in the Philippines Industries, LAP LAMBERT Academic Publishing.

McLellan, J. and Moustafa, E. (2011), "Management accounting practices in the Gulf cooperative countries", International Journal of Business, Accounting, and Finance, Vol. 5 No. 1, pp. 129-142.

Mazanai, M. (2012), "Impact of just-in-time (JIT) inventory system on efficiency, quality and flexibility among manufacturing sector, small and medium enterprise (SMEs) in South Africa", African Journal of Business Management, Vol. 6 No. 17, p. 5786.

Nishimura, A. (2005), "Management accounting practices of japanese affiliates in Singapore, Malaysia and Thailand", in Nishimura, A. and Willett, R. (Eds), Management Accounting in Asia, Vol. 102 No. 33, Thomson, pp. 11940-11944.

Otley, D.T. (1980), "The contingency theory of management accounting: achievement and prognosis", Readings in Accounting for Management Control, Springer, Boston, MA, pp. 83-106.

Oyerogba, E.O. (2015), "Management accounting practices in the developing economies: the case of Nigeria listed companies", The Journal of Accounting and Management, Vol. 5 No. 2.

Paaso, I. (2013), "The effects of contingency factors on management control systems: an empirical study at CERN", CERN-THESIS-2013-308, available at: https://cds.cern.ch/record/1605536

Porter, D.M. (1980), "The Waltham system and early American textile cost accounting 1813-1848", Accounting Historians Journal, Vol. 7 No. 1, pp. 1-15.

Shotter, M. (1999), "The origin and development of management accounting".

Ššksa, L. (2016), "The contingency factors affecting management accounting in Czech companies", Acta Universitatis Agriculturae et Silviculturae Mendelianae Brunensis, Vol. 64 No. 4, pp. 1383-1392.

Sleihat, N., Al-Nimer, M. and Almahamid, S. (2012), "An exploratory study of the level of sophistication of management accounting practices in Jordan”, International Business Research, Vol. 5 No. 9, p. 217.

Sulaiman, M.B., Nazli Nik Ahmad, N. and Alwi, N. (2004), "Management accounting practices in selected Asian countries: a review of the literature", Managerial Auditing Journal, Vol. 19 No. 4, pp. 493-508.

Sunarni, C.W. (2015), "Management accounting practices at hospitality business in Yogyakarta, Indonesia", Review of Integrative Business and Economics Research, Vol. 4 No. 1, p. 380.

Zehir, C., Ertosun, Ö.G., Zehir, S. and Müceldilli, B. (2012), “Total quality management practices' effects on quality performance and innovative performance", Procedia-Social and Behavioral Sciences, Vol. 41, pp. 273-280.

\section{Further reading}

Adesina, O.T. and Ikhu-Omoregbe, S. (2015), "Accounting information and profit planning the case Nigeria listed manufacturing companies", European Journal of Accounting Auditing and Finance Research, Vol. 3 No. 4, pp. 86-97.

Ahmad, K. (2017), "The implementation of management accounting practice and its relationship with performance in small and medium enterprises sector", International Review of Management and Marketing, Vol. 7 No. 1.

Al-Mawali, H. (2013), "Performance consequences of management accounting system information usage in Jordan”, Business \& Economic Horizons, Vol. 9 No. 1.

Ax, C. and Greve, J. (2017), "Adoption of management accounting innovations: Organizational culture compatibility and perceived outcomes", Management Accounting Research, Vol. 34, pp. 59-74.

Azudin, A. and Mansor, N. (2017), "Management accounting practices of SMEs: the impact of organizational DNA, business potential and operational technology", Asia Pacific Management Review. 
Butler, S.A. and Ghosh, D. (2015), "Individual differences in managerial accounting judgments and decision making", The British Accounting Review, Vol. 47 No. 1, pp. 33-45.

Čadež, N., Dlauchy, D., Raspor, P. and Péter, G. (2013), "Ogataea kolombanensis sp. nov., Ogataea histrianica sp. nov. and Ogataea deakii sp. nov., three novel yeast species from plant sources", International Journal of Systematic and Evolutionary Microbiology, Vol. 63 No. 8, pp. 3115-3123.

Cadez, S. and Guilding, C. (2012), "Strategy, strategic management accounting and performance: a configurational analysis", Industrial Management \& Data Systems, Vol. 112 No. 3, pp. 484-501.

Ern, S.Y., Abdullah, A. and Yau, F.S. (2016), "Contingency factors influencing MAS design of manufacturing firms in Malaysia”, Asian Journal of Accounting and Governance, Vol. 7, pp. 1-9.

Fullerton, R.R. and McWatters, C.S. (2002), "The role of performance measures and incentive systems in relation to the degree of JIT implementation”, Accounting, Organizations and Society, Vol. 27 No. 8, pp. 711-735.

Giovannoni, E., Maraghini, M.P. and Riccaboni, A. (2011), "Transmitting knowledge across generations: the role of management accounting practices", Family Business Review, Vol. 24 No. 2, pp. 126-150.

Ketokivi, M.A. and Schroeder, R.G. (2003), "Strategic, structural-contingency and institutional explanations in the diffusion of innovative manufacturing practices", Journal of Operations Management, Vol. 22 No. 1, pp. 63-89.

Langfield-Smith, K. (1997), "Management control systems and strategy: a critical review”, Accounting, Organizations and Society, Vol. 22 No. 2, pp. 207-232.

Mia, L. and Winata, L. (2008), "Manufacturing strategy, broad scope MAS information and information and communication technology”, The British Accounting Review, Vol. 40 No. 2, pp. 182-192.

Mohamad, N.A., Karami, M., Bajuri, N.H. and Asgharizade, E. (2015), "The relationship among strategy, competition and management accounting systems on organizational performance", European Online Journal of Natural and Social Sciences, Vol. 4 No. 3, p. 565.

Nuhu, N.A., Baird, K. and Bala Appuhamilage, A. (2017), "The adoption and success of contemporary management accounting practices in the public sector", Asian Review of Accounting, Vol. 25 No. 1, pp. 106-126.

Salehi, M., Alipour, M. and Ramazani, M. (2010), "Impact of JIT on firms' financial performance: some Iranian evidence".

Sunarni, C.W. (2013), "Management accounting practices and the role of management accountant: evidence from manufacturing companies throughout Yogyakarta, Indonesia", Review of Integrative Business and Economics Research, Vol. 2 No. 2, p. 616.

Tarmidi, M., Rashid, A.A. and Abdullah, W.M.T.W. (2017), "An analysis of computerized accounting system security threats in Malaysian public listed companies", Terengganu International Finance and Economics Journal, Vol. 2 No. 1, pp. 28-35.

Tuan, M. (1998), Forever Foreigners or Honorary Whites?: The Asian Ethnic Experience Today, Rutgers University Press. University of Huddersfield (2003).

Xydias-Lobo, M., Tilt, C. and Forsaith, D. (2004), "The future of management accounting: a South Australian perspective", Journal of Applied Management Accounting Research, Vol. 2 No. 1, p. 55.

Zaleha Abdul Rasid, S., Ruhana Isa, C. and Khairuzzaman Wan Ismail, W. (2014), "Management accounting systems, enterprise risk management and organizational performance in financial institutions", Asian Review of Accounting, Vol. 22 No. 2, pp. 128-144.

\section{Corresponding author}

Ayaz ul Haq can be contacted at: publications@cbsr.com.pk

For instructions on how to order reprints of this article, please visit our website:

www.emeraldgrouppublishing.com/licensing/reprints.htm

Or contact us for further details: permissions@emeraldinsight.com 